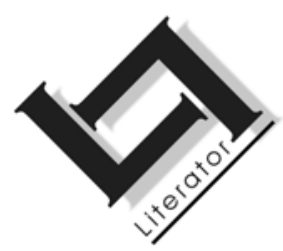

\title{
Richard Murphy: a life in writing
}

\author{
Elsa Meihuizen \\ Department Afrikaans \\ University of Zululand \\ KWADLANGEZWA \\ E-mail: emeihuizen@pan.uzulu.ac.za
}

\begin{abstract}
Richard Murphy: a life in writing

The Irish poet Richard Murphy published his autobiography "The kick: a life among writers" in 2003. From a slightly different perspective the subtitle of this work could be rewritten as "A life in writing" since it is an account of the agencies that moulded a life devoted to creative writing which forms the book's essential impetus. The memoir is based on notebooks which Murphy kept throughout his life "to hold the scraps of verse, elusive images, dreams, desires and revelations" to be developed into poetry. Apart from contextualising his poetry by registering the relationships, circumstances and landscapes from which it germinated, Murphy also tells of the creative process itself and the personal poetics underlying this process. This article explores what is regarded as the central determining feature of Murphy's identity as poet, namely the relationship between the creative self and a particular place, where the concept of "place" is seen as a cultural palimpsest which represents not only physical qualities, but also the shaping and development of the landscape through time according to a certain way of life.
\end{abstract}

\section{Opsomming}

\section{Richard Murphy: 'n lewe as skrywer}

Die lerse digter Richard Murphy publiseer sy outobiografie "The kick: a life among writers" in 2003. Vanuit 'n effens ander invalshoek sou die subtitel van hierdie werk herskryf kon word as "'n Lewe as skrywer", aangesien dit primêr handel oor die kragte wat werksaam is in die vorming van 'n lewe wat gewy aan is kreatiewe skryfwerk. Die outobiografie is gebaseer op aantekeninge wat Murphy sy lewe lank bygehou het om "fragmente van gedigte, ontwykende beelde, drome, begeertes 
en onthullings" wat moontlik later tot poësie kon ontwikkel, neer te skryf. Afgesien van die feit dat Murphy se memoir sy poësie kontekstualiseer deurdat dit vertel van die verhoudings, omstandighede en landskappe waaruit dit ontstaan het, handel dit ook oor die kreatiewe proses self en oor die persoonlike poëtika wat hierdie proses onderlê. In hierdie artikel word ondersoek ingestel na wat beskou word as die sentrale dryfkrag in Murphy se identiteit as digter, naamlik die verhouding tussen die kreatiewe self en 'n spesifieke plek. Die begrip "plek" behels nie net die fisiese nie, maar word ook beskou as 'n kulturele palimpses wat die vorming en ontwikkeling van die landskap volgens 'n bepaalde lewenswyse verteenwoordig.

\section{Introductory}

Richard Murphy is the author of six volumes of poetry $\mathbf{1}$ brought together in Selected Poems (1979), New Selected Poems (1989) and Collected Poems 1952-2000 (2001). Murphy's poetry was often first published in British and American journals or broadcast on the $\mathrm{BBC}$, and in that way attracted wide public attention. He was awarded several literary prizes ${ }^{2}$ and received recognition as a writer of stature through his enrolment as Fellow of the Royal Society of Literature in 1969, as well as through invitations to participate in poetry readings and to teach creative writing at several universities in America, Britain, Ireland and Australia between 1963 and 1994. In 2002 Murphy published his memoir entitled The kick: a life among writers. In the opening paragraph of the "Acknowledgements" preceding his narrative Murphy writes: "Twelve years ago in Dublin, the poet and critic Dennis O'Driscoll, after reading many of my notebooks, encouraged me to write this memoir" (Murphy, 2003:v). ${ }^{3}$ The notebooks referred to in this acknowledgement are those which, as we learn later in the memoir, Murphy kept from the age of twenty seven to record "scraps of verse, elusive images, dreams, desires

1 The archaeology of love (1955), Sailing to an island (1963), The battle of Aughrim (1968), High Island (1974), The price of stone (1985) and The mirror wall (1989).

2 These awards include the A.E. Memorial Award for Poetry in Ireland (1951), first prize in the Guiness Awards, Cheltenham (1962), British Arts Council Awards (1967 and 1976), American-Irish Foundation Award (1983) and the Poetry Book Society Translation Award (1989).

3 I used the paperback version of the memoir published in 2003. Since I refer to Murphy (2003) extensively, references to this source in the rest of the article consist only of page numbers given in brackets. 
and revelations" which he hoped to turn into "poetry that might be accepted by T.S. Eliot at Faber" (p. 154). This conscious recording of significant events and thoughts accounts for the rich details of Murphy's life rendered in his memoir, and more significantly, it reflects a lifelong preoccupation with the writing of poetry. 4

The subtitle of the memoir, "A life among writers", is informed by the fact that Murphy writes extensively about his brief encounters and more enduring relationships with a spectrum of writers in England, Ireland, America and in Sri Lanka. These include C.S. Lewis, Stephen Spender, Patrick Kavanagh, Desmond O'Grady, James Merril, W.H. Auden, Theodore Roethke, Robert Lowell, Conor Cruise O'Brien, Thomas Kinsella, Richard Selig, James Dicky, Seamus Heaney, Iris Murdoch, John McGahern, Ted Hughes, and Sylvia Plath. Murphy also reflects on the formative and enriching influence on his life of writers such as Shakespeare, Coleridge, Wordsworth, Yeats, Charles Williams, and Jeremy Taylor. To this second group belongs the philosopher Ludwig Wittgenstein, who spent a few months in a cottage in Rosroe two years before it was rented by Murphy in 1951. Although Murphy did not know the work of Wittgenstein, he turned the story of the philosopher's stay in Ireland as told to him by the caretaker Tommy Mulkerrins (p. 134135 ) into the poem "The philosopher and the birds". 5

The subtitle thus highlights an important and sustained theme in the memoir, but I would like to argue that it would be possible, and indeed appropriate, to rewrite this subtitle as "A life in writing" since it is an account of the agencies that moulded a life devoted to creative writing which forms the book's essential impetus. Apart from contextualising his poetry by telling of the relationships, circumstances and landscapes from which it germinated, Murphy's tale is also that of the creative process itself and of a personal poetics underlying this process.

\section{Basic facts of Richard Murphy's life}

Richard Murphy was born on 6 August 1927 in Milford House, Co. Mayo in north-west Ireland to an Anglo-Irish family. He spent his first two and a half years in Ceylon (now Sri-Lanka), where his father

$4 \quad$ Murphy's notebooks are kept in the McFarlin Library at the University of Tulsa.

5 The poem was read on the BBC in 1953 and later included in Sailing to an island (1963). In Collected Poems 1952-2000 the title is changed to "Wittgenstein and the birds". 
worked in the Colonial Service. After returning to Ireland in 1930 the family sometimes stayed in Dublin but most of the time in a bungalow called Ardnasilla Lodge close to the shore of Lough Corrib. Another period of about three years in Ceylon followed before the Murphy children and their mother returned "home to Ireland for good" (p. 37) in 1935 when the poet was seven years old. Murphy received his formal education at Baymount Preparatory School in Dublin, Canterbury Cathedral Choir School, the King's School, Wellington College, and Magdalen College, Oxford. Most of his holidays were spent in west Ireland at Milford with his grandparents and his mother, and later, while he was studying at Oxford, on his own in cottages in more remote places such as near Screebe by the Camus river or at Lecknavarna at the bottom of Ben Choona.

The early life of the author thus follows a pattern of returning to Ireland after periods of time spent elsewhere, and throughout his life this returning to Ireland, or what Murphy describes as being "drawn back to a place I loved" (p. 96) constitutes one of the main features of the poet's life. This "drawn back" happened in the following stages of his life: during his childhood; for holidays while he was at school and at university; after working for his father in the Bahamas in 1948 and 1949, followed by two years in London; in 1953 after a short spell of teaching and reviewing poetry in London; in 1955 after he spent some time in Greece and in Paris where he met Patricia Avis whom he married in May of that year; in 1959 after his marriage failed and he settled in Cleggan where he made a living for the next seven years by taking tourists on day trips on two Galway hookers; after poetry readings and periods of teaching at universities; after visits to Sri Lanka in 1984, 1987 and 1991; and periodically after he settled in South Africa in 1997.

\section{Poetics}

\subsection{General principles}

It would be possible to extract from Murphy's memoir several general principles underlying his poetic oeuvre, such as the following: if poetry is well made, it can confer immortality on the poet and his loved ones; poetry, rather than the church or religion, can offer redemption from loneliness, from fear of death, from guilt; and that through poetry a connection with the past can be established. Murphy's personal poetics also includes the belief that poetry should come to the true poet as a revelation or inspiration, as if granted by the Holy Spirit in a vision, without being soiled by effort. We can also 
deduce from The kick that for Murphy poetry resembles music, that the structure of a poem should resemble the symmetry of a body or a building; that there is a link between creative energy and being in a particular place; that poetry should not "lie"; and that "a narrative poetry that many critics believed the modern novel had made obsolete" (p. 132) is always his first choice.

In this article I would like to single out and explore what I regard as the central determining feature of Murphy's identity as poet, namely the relationship between the creative self and a particular place. The construction of identity 6 is generally acknowledged as a complex process informed by a variety of factors such as gender, class, ethnicity, religion, nationality, sexuality, history, and space. Recognition is also given to the interaction between individual identity and group identity. The concept of "place" fundamentally underlies the intricate network of forces in the formation of individual or group identity in the Heideggerean sense of human endeavour to conceptualise experience of time and space, as pointed out in Wenzel (2003:317). With reference to Crang (1998) Wenzel sees the place inhabited by the individual or group as a cultural palimpsest which represents not only physical qualities but also the shaping and development of the landscape through time according to a certain way of life (or, social ideology).

For Murphy the landscape providing the cultural palimpsest for his poetry is the north-west of Ireland, to which he perpetually returns throughout his life and which he describes as "that mournful, impoverished, tempestuous country ... the most beautiful place in the world" (p. 96). The connection for Murphy between being in this particular place and writing poetry has been commented on by Seamus Heaney (1977). My exploration of the relationship between the creative self and place in Murphy's writing is made in the light of this article since I regard Heaney's views to be confirmed when read against the information on Murphy's life and work provided in The kick, as well as against his poetry.

\subsection{The creative self and place}

Richard Murphy tells us in The kick that when he asked himself as a boy of eight what he was going to be "to save the world and (him)self" (p. 44), he thought of becoming a doctor with genteel 
bedside manners, or one fighting malaria and demons in Ceylon. He also tells us that at this age while he was at boarding school and the only way of communicating with his loved ones was through writing letters, he "came to love writing for its own sake" (p. 42). This love of writing and the written word was encouraged by people such as Miss Sarah Stokes, the private tutor of the Murphy children during the war, and also by the teachers Robin Gordon-Walker and T.S. Dorsch at Wellington College. By the age of seventeen when Murphy's notion of being destined to "save" the world and himself was given a greater sense of urgency by the Second World War, he became convinced that he could do this through writing poetry:

The ambition to write poetry took root in my mind when I was reading Shakespeare's sonnets and the poetry of Donne, Herbert, Marvell, Milton and Wordsworth. By the summer of 1944, the Germans had started to launch their first flying bombs to fall on England, and Wellington was within their range ... Scared of bombs, excoriated by my housemaster - a survivor of the Somme - for my Irish lack of British patriotism, I took refuge in the Renaissance conceit that a poem, if well made, could last longer than its maker, giving life after death to himself and his loved ones in the mind of his readers (p. 85).

After a year and a half at Oxford where Murphy was unsuccessful in both his studies and his ambition to write poetry, he decided to return to Milford, "rediscovered" Connemara, and rented a primitive cottage near Screebe where he came to the realisation that it would be here that he would write his poetry:

By the Camus River, with the smell of peat smoke, the sound of rain dashing on tiny windowpanes, and the lyrical voices of my poor landlord's family who spoke almost nothing but Irish, my verse began to flow ... Here I became convinced with religious intensity that the poetry I wanted to write would be written in Connemara (p. 97).

The ambitious task of writing a tragedy about a mayor of Galway who hanged his son which Murphy set for himself on this occasion came to nothing, but the conviction regarding the place remained, and although it would take almost five years, he returned, as soon as he had the means to do so, to the Connemara coast in April 1951 where he would eventually write the poetry published in Sailing to an island. 


\subsubsection{The spirit of the pleasure ground}

Heaney (1977) deals with Murphy's first three volumes of poetry Sailing to an island (1963), The battle of Aughrim (1968) and High Island (1974), but he also explores what he describes as the "groundplan" of Murphy's poetic imagination. The key to this is for Heaney to be found in Murphy's contribution to a series of BBC talks called Writers on themselves broadcast early in 1963 and published under the same title in 1964. Murphy calls his contribution "The pleasure ground", referring to a walled garden attached to Milford House, his grandparents' home in the west of Ireland. The Murphy children lived here with their mother for a period of time during the Second World War. Murphy tells us that their mother devoted herself to the restoration of the garden which had been in her family since the victories of William of Orange in the 17th century but which was in a state of neglect when they arrived there. Of the period he and his family spent in the pleasure ground Murphy writes that is was the happiest time of his life, where everything, even the hardships imposed by the war and the learning of "poetry, and music, and painting, even mathematics" became "an effortless delight" (Murphy, 1964:66).

Heaney points out that in "The pleasure ground" Murphy makes a connection between his childhood entrancement with this garden and his later realisation that the Connemara coast was the place in which he would write his poetry. This is particularly evident in the last sentence of the essay:

As I grew older the garden grew wilder, losing its form as trees were felled, and its spirit as the old people died and the young left the country; so I searched more and more into the origins of that garden till I found them finally in the sea (Murphy, 1964:66).

Heaney picks up as the crucial element in this sentence the idea of loss of a particular "form" and "spirit" for which Murphy desired to identify the origins, and which he "found ... finally in the sea". The sea which Murphy has in mind here is the north-west coast of Ireland. Heaney correctly deduces that the reason why Murphy finds what he is looking for in this particular location ties in with on the one hand his association of the Irish Atlantic coast with happiness experienced there as a child, and on the other hand with an ambivalence towards his ancestral inheritance. 
The period of childhood happiness Heaney has in mind is the summer of 1935 which the family spent at Rosleague near Letterfreck and about which Murphy writes in the memoir:

My love for the north-west corner of Connemara goes back to the summer of my eighth birthday at Rosleague, a big ivy-clad house standing high among trees with a view of the Diamond Mountain and the rotting hulks of trawlers at the quay of Letterfreck. Mrs. Browne, a Twining of Twining's Tea, had let the house to my father for his long leave from Ceylon in 1935. It was the last time and place in which all five of us children were to live at home with both parents and Nanny (p. 39).

The nature of Murphy's ambivalence towards his ancestral inheritance becomes evident towards the end of the 1964 essay where Murphy tells us that the period of happiness in the pleasure ground was short-lived because some members of the family died and others had to leave, so that the garden went to wrack and ruin. With only his grandmother left in charge of it, Murphy feels there was no longer any masculine energy in the place to uphold the earlier form and spirit, and instead of the earlier happiness he now felt lost and guilty here. These feelings are in Heaney's view best understood in the light of Yeats' meditations in "Ancestral houses". For Heaney this means that Murphy knows that the greatness of the ancestral order was founded upon violence, and that he is ready to accept the debilitation of the Protestant Irish nation flowing from this historical background. Heaney links Murphy's sensitivity regarding the moral ambiguity of his inheritance to the influence of his grandmother. ${ }^{7}$ He points out that Murphy tells us that she had been brought up on the far side of the Connemara mountains, that it was in her company that Murphy visited this area occasionally during the pleasure ground period, and that it was these visits which, on one side, renewed Murphy's earlier happy childhood memories, while on the other, they lead to the particular consciousness of the people of this area described in the following paragraph from Murphy (1964) quoted by Heaney:

7 In his memoir Murphy writes at length on his grandmother, Lucy Mary Ormsbury, and in particular about her selfless work as healer of everyone, regardless of who they were (p. 65, 147-147). In the long poem "Woman of the house" written in her memory Murphy says of this kindness: "She bandaged the wounds that poverty caused / In the house that famine labourers built / Gave her hands to cure impossible wrong / In a useless way, and was loved for it." 
These people lived on five or two-and-a-half acre holdings, and we loved them better than our own relations, or the children at the rectory parties we had to attend. They were truly Irish, and that's what my brother and I wanted to be ... Stones, salmonfalls, rain-clouds and drownings had entered their minds, loaded with ancestral bias. Their manners seemed more natural than ours, and their voices used tones that rasped excitingly against the hymn-tune harmonies we were used to. We wished we could talk like them (Murphy, 1964:65-66).

Heaney then formulates the connection he sees in the "groundplan" of Murphy's poetic imagination between the Ascendancy garden and the seascapes of Connemara as follows:

To wish you could talk like somebody else is to seek to begin again with a new identity. It seems to me that Murphy exchanged the stewardship of his inherited pleasure ground for the stewardship of his chosen art; his 'masculine energy' was directed to the mastery of a way of life among boats that would make him an initiate among the 'truly Irish', and directed also to the mastery of the craft of poetry that would enable the rebirth of the self as an artist. As an artist, he is impersonal and in control. The contents of his mind, the drift of his feelings, the conflict of his loyalties and recognitions are all materials to be worked and the poem will have to be a vessel sturdy enough to take the strain of conflicting Irish winds. As Irish artist, both the pleasure ground of the elemental landscape, with its indigenous inhabitants, and the pleasure ground of the ancestral estate, with its colonial ethos, are to be his theme (Heaney, 1977:22).

For Heaney Murphy's search for the origins of the ruined ancestral garden then leads to a rebirth of the self as an artist. This rebirth entails the assumption of a more "truly Irish" identity, more like the inhabitants of the north-west Irish seascapes, by living in their elemental landscape and mastering their way of life.

The connection for Murphy between the underlying ethos of the ancestral estate and that of these seascapes is evident from the following description of his first arrival on Inishbofin:

As we sailed through a short narrow channel to a little inner harbour, watched by a group of fishermen on the quay, I felt we were arriving among descendants of people long ago marooned on an island where they lived in the fear of God and believed in miracles, travelled on horseback, and lit their houses with oil lamps and candles as we had done at Milford during the war ... 
I had been trying for more than a year to reach a mythical island in a poem based on a legend. Now I had really landed on an island where men had turned their seafaring lives into legends they recounted to each other in the island's only pub ... Two men I met there ... were to influence my poetry, not only with their legends but their style ... Pateen Clogherty ... broke into song, a ballad ... about the loss with all hands of a hooker called the Maisie on St. John's day in the year of his birth ... Already I had been grasped by the hand of an ancient mariner called Pat Concannon, who had begun to tell me a story that would take years to finish... As he began to draw me into his legend, it caught my mind with a drowning man's grip and would not let go. In future I would be drawn back to the island to learn more about legends, seamanship and the art of storytelling before being able to write a poem in honour of his courage and the island fisherman's way of life (p. 141-142).

It is clear from this quotation that Murphy's arrival in this particular place, his physically being in it, is what eventually enabled him to write his poetry. In order to pass the test of being "truly Irish" he had to master the particular way of life dictated by the harsh physical landscapes of the Irish Atlantic coast. In passing this test he would reassert the masculine energy which once underpinned the form and spirit of the ancestral garden, and since this reassertion takes place within a "truly Irish" landscape it will alleviate the ambiguities of his ascendancy inheritance, will earn him a position inside the circle of the "truly Irish", and ultimately enable him to "talk like them" through his poetry.

The two landscapes of Murphy's poetic imagination speak to an extent through all his poetry, but as specific examples the following can be singled out: "Sailing to an island", "The last Galway hooker", "Auction", "Epitaph on a fir tree", "The woman of the house", "Droit de Seigneur", "The drowning of a novice", "Connemara Marble", "The Cleggan disaster", "The Battle of Aughrim", "Seals at High Island", "Walking on Sunday", "Pat Cloherty's version of The Maisie", "Brian Boru's well", "The reading lesson", "Storm Petrel" and "High Island".

\subsubsection{Structure and structuring}

Heaney's summation of the "groundplan" of Murphy's poetry also rings true in the sense that it sheds light on a preoccupation with structure and structuring both in the physical environment in which the creative product takes shape and in the construction of that product. 
The two connected worlds which Heaney identifies as the breeding ground for Murphy's poetry are environments given to an essential emphasis on structure, comprising an ordering spirit, decorum, and an established and principled way of life. From the description of Murphy's first arrival on Inishbofin quoted earlier it is for instance clear that the islanders' way of life has remained unchanged, set in its traditional ways, as if they were "marooned long ago"; and they still "lived in the fear of God and believed in miracles, travelled on horseback, and lit their houses with oil lamps and candles" as their forefathers did. In his description of the pleasure ground at Milford, Murphy significantly equates the nurturing spirit of the garden with order. The original garden "... once had a lovers' walk marked out by cedars of Lebanon and Florence Court yews in methodical pairs with lawns and copper beeches in the centre" (Murphy, 1964:62). As has been pointed out earlier, the garden had been neglected for years before Murphy arrived there as a child with his mother, brothers and sisters, but they devoted themselves to the restoration of its decorous features, and it was when these eventually "fell back into decay" that the spirit of the pleasure ground was lost:

The pleasure ground period didn't last forever. Some of us went to boarding schools in England, other settled abroad ... The garden fell back into decay. Chickens scratched on my mother's lupin-beds; hay was scythed on the tennis court, the laurels and the rabbits increased; the beech was cut down and sold for firewood; cows strayed through the rusty gates ... Now my grandmother was mistress of a beautiful disorder ... the discipline of the garden had died. The spirit that I was looking for in the yew-berry, the fig and the beech-tree had withdrawn that spirit which had once made poetry and music and painting, even mathematics, an effortless delight (Murphy, 1964:62).

The formative influence of a structured physical reality upon the creative product for Murphy is reflected for instance in his choice of the notebooks in which he recorded significant thoughts and experiences. He tells us that the idea of keeping such a record occurred to him in 1954 when he studied at the Sorbonne in Paris, and of the type of notebook he chose, he says:

... I discovered and bought ... a small notebook for mathematicians, the pages lined with little squares, bound in green boards, quite cheap. I imagined that as numbers underlie music, and a score is essential for composition, so the page might hold in its net the music of poetry, and prevent words from swimming into measureless prolixity. As a symbol of perfection, the mesh of vertical and horizontal lines, which 
every word written by hand with a fountain pen would overlay, might exert day by day a subtle influence not to lie (p. 154).

The physical dimensions of the page delimited as in mathematics or music serve as a template for the type of poetry Murphy wants to write. This type of page would serve as "a symbol of perfection", guarding against the vice of imperfection by barring words with "measureless prolixity" and the tendency "to lie".

That a structured physical space can serve as inducement for the creative act is also reflected in what Murphy says about the house which he called the Hexagon 8 and which he built for himself on Omey Island in 1974:

In the centre of this 1980s beehive hut, an oak hexagonal pole supported a flat roof. Around that pole was a teak hexagonal table on a stone hexagonal pillar. Whenever I entered, harassed by rain, wind and the anxieties of life on the mainland, the figure of the hexagon, repeated like a musical theme with variations in the walls, the table and the ceiling, calmed me with a sense of concentricity and gave me the centripetal energy I needed to sit down, take out a notebook and pen, and write (p. 309).

The building in which everything is carefully structured in the form of hexagons provides the repose and the centred energy needed for writing. A building for Murphy can be equated with the body, both being in essence symmetrical, a quality he also deems necessary in poetry, as is evident from the following comment Murphy made about his teaching of a creative writing course at Colgate University in 1971:

I stressed the value of mastering metre and rhyme before attempting to write free verse. But my theories that the iamb derives from the heartbeat and that the structure of a poem needs a body's or a building's symmetry put me out of key with the time. Metrical rhymed poetry had never come easily to me, nor did I expect it to be easy for students who equated poetry with self-expression. Too often l'd written myself to a standstill

8 The hexagon is an important figure for Murphy, stemming from the time of his birth at Milford when there was a swarm of bees in the roof of the room in which he was born. The hexagon represents the idea of "life" or "new life" as expressed for instance in "Birthplace", "Newgrange" and "Beehive cell" in the sonnet sequence "The price of stone". 
going over and over the same lines or stanzas, making no progress (p. 295).

This quotation captures an interesting paradox in Murphy regarding structure, since it illustrates that notwithstanding his preoccupation with formal qualities, he is aware that an overemphasis on structure can, and often does, work against the creative writing process and in a more general sense against the creative forces of life. This awareness is for instance reflected by a section from The kick which forms part of Murphy's coverage of the period in the second half of the 1960s during which he was intensely involved in building a house using granite collected from the remnants of abandoned cottages in the Cleggan area. Murphy comments as follows on his work routine while living in the New Forge, the house he built for himself:

The attic had become my study in the New Forge, where I still used notebooks lined with small squares from France for the first or the fiftieth draft of a poem before typing it ... A note written after two lines of verse, that were later discarded from a poem ('Little Hunger') about making 'integral' the granite remnants of ruined houses shows how the poet as builder wrote himself into a block.

Did I need stone to build a house or a house to build with stone?

Having written those two lines after much effort, I relaxed, expecting to return with renewed vigour, but could not come to grips again, the gathered energy was gone ... I could only repeat and repeat and repeat, harking to the sound of words, while chipping away their sense ... The search for a rhyme stalled me (p. 273-274).

The negative influence of the preoccupation with structure and constructing on the creative forces of life is typically reflected in the poem "Stone Mania"9 in which the speaker expresses remorse for his "passion for building in granite" as a consequence of which he "never had a moment in the present for writing about / the moments that were passing away". On a much larger scale this theme is captured in the autobiographical sonnet sequence "The price of

9 Published originally as "The price of stone" in the London Magazine, March 1980, p. 8-9 and later as "Stone mania" in the "Care" section of the volume The price of stone and earlier poems (1985). "Stone mania" also appears in Murphy (1979; 1989 and 2001). 
stone" published in 1985.10 In this sequence of fifty sonnets Murphy's life story is told from the perspective of man-made structures personally significant to him. In the first nine sonnets these structures are landmarks in Dublin, and although the stories told by the different structures vary according to each one's nature, history and setting, they coincide in telling of a state of crisis brought about by degeneration. In relating their own fates the landmarks focus on the lifeless, inanimate matter constituting them and on their prominent, characteristic structural features. Often these descriptions are formulated in such a way that structure and/or inanimate matter is linked to an act of communication that has become meaningless and often reflects disillusionment. The preoccupation with structure in various senses reflects attempts to safeguard oneself against the perilous nature of life by seeking security in that which can be structured or constructed, while at the same time it represents as "the price of stone" a shying away from, or losing the natural creative forces of life. In contrast, the last sonnet in the sequence, "Natural son", represents a redefinition of the nature of life through an acceptance of its fragility. This acceptance is connected to a shift in the nature of the structures involved. The speaker is no longer a building, but the author himself, addressing his own new-born son, and the structure focused on here is not an inanimate one, but the womb, portrayed as the "house" of the unborn child.

\subsubsection{The artist as impersonal and in control}

A problematic aspect of Heaney's formulation of the "groundplan" of Murphy's poetic imagination is the judgment that through the rebirth of the creative self in the "truly Irish" Connemara seascapes the poet becomes "impersonal and in control" (Heaney, 1977:22). Murphy's Irish experience as reflected in his poetry is in fact personal and his writing often reflects self-doubt, stemming from an awareness of the tensions and ambiguities contained in himself and the world he inhabits.

We see this typically in "Sailing to an island" the title poem of his first volume of poetry published in 1963 . The poem is based on a boat trip Murphy undertook with his family to Inishbofin. The tale of this trip is narrated in the first person, and on arrival the narrator focuses 
on his awareness that he and his group are being scrutinised and judged by the islanders:

What will the islanders think of our folly?

The whispering spontaneous reception committee

Nods and smokes by the calm jetty.

Am I jealous of these courteous fisherman

Who hand us ashore, for knowing the sea

Intimately, for respecting the storm

That took nine of their men on one bad night

And five from Rossadillisk in this very boat?

Their harbour is sheltered. They are slow to tell

The story again. There is local pride

In their home-built ships.

We are advised to return next day by the mail.

It is the islanders who are in control of this world, secure in their knowledge of the sea, proud of their craft, sheltered in their harbour, and not willing to include strangers in their legends and histories. The narrator remains painfully aware of his own lack of all these certainties and of his position as an outsider who is "advised to return next day by the mail".

Personal tensions and ambiguities are not only reflected in poems based on Murphy's own experiences, but also when he writes about the events of a more general national nature such as in the sequence "The battle of Aughrim". In this long sequence Murphy's subject is the historical battle fought on 12 July 1691 on Kilcommodon Hill in western Ireland, which claimed 6000 lives when the Catholic forces of James II (backed up by Louis XIV) clashed against the English Protestant forces of his son-in-law, William of Orange. One of the most striking features of "The battle of Aughrim"11 is the wide spectrum of characters through which the story of this terrible carnage and its consequences is told. The poem is prefaced by a "Historical note" and consists of four sections based on the different temporal positions "Now", "Before", "During" and "After", and narrated from the point of view of various focal characters who played different rolls in the battle. The poem also brings to life characters representing the social and political state of affairs which resulted from the Irish defeat. The purpose of bringing this spectrum of characters to life is to answer the epic question "Who owns the land where musket-balls are buried / In blackthorn 
roots on the eskar, the drained bogs / Where sheep browse, and credal war miscarried?" posed in the opening line of the "Now" sequence. In the unfolding story told by and through these characters the point of view switches between an omniscient narrator telling the story from outside and internal focalisation where the narrative is presented from the point of view and from within the restricted fields of knowledge of specific focal characters. The characters used for internal focalising are from the past or from more recent times, but also include the first person narrator of "Now" who visits Battle Hill on horseback, whose dreams are reported in "Green Martyrs", who recounts the Orange March and the homecoming of Casement's skeleton, who attends the symposium on Ireland's Jacobite war in "Historical Society", who tells about the history of the slate he picks up from a nettlebed to pave his garden path with in "Slate", whose kinsman destroyed "bronze-aged raths" and trees on their Cromwellian demesne in "Inheritance", who is "saved from Rome" through Protestant ritual in "Christening", and who tells his reader in "History" that "The battle cause ... / Has a beginning in my blood". The reader with sufficient biographical knowledge of the author of the poem will realise that this narrator can be no-one else but Richard Murphy himself, a fact deliberately established in the poem and necessary for us to grasp for an understanding of it. Richard Murphy says about writing "The battle of Aughrim" in The kick:

I was trying to come to terms with my own army heritage, and with not having served in the war that was brought to an end by the bomb on Hiroshima on my eighteenth birthday. That heritage accounts for the coolness of tone and the demythologizing ironies of the poem ... The poem grew slowly, because organically, from bits and pieces of my life and reading in Ireland between 1962 and 1967, not as a setpiece epic about a battle in the seventeenth century. My underlying wish was to unite my divided self, as a renegade from a family of Protestant imperialists, in our divided country in a sequence faithful to the disunity of both (p. 220).

What Murphy describes here as an effort "to come to terms" with his own heritage, is echoed in the poem by the epic question, but that question is not just a general summarising and focusing of the narrative such as in the classical epic poem - it is asked out of personal need by Richard Murphy in order to solve the conflicts and ironies he is so intensely aware of in himself. 


\section{Conclusion}

Although autobiographical texts are often highly manipulative and selective, a memoir such as The kick remains a valuable source of information on the life and work of the artist. Robert Sheppard begins an essay entitled "The necessity of poetics" with the following words:

Despite the present prominence of the critic, it is to the poet we must turn for poetics. With few exceptions, those qualified to theorise about poetry are those who write it. And the most effective poetics take the form of an apologia for one particular style of writing - usually the poet's own (Sheppard, 2000:1).

Murphy's comments on his life as a creative writer in The kick certainly include elements of an apologia regarding his style of writing, but the book is in essence rather an apologia for a style of living in which the writing of poetry became possible. This style of living was for Murphy archetypically present in the sense of decorum associated with the pleasure ground of his childhood, and rediscovered in the "truly Irish" way of life of the seascapes of the Atlantic Irish coast.

\section{List of references}

APPIAH, KWAME ANTHONY \& GATES, HENRY LOUIS, JR. 1995. Identities. Chicago: Chicago University Press.

BLUNT, ALLISON \& ROSE, GILLIAN, eds. 1994. Writing women and space: colonial and postcolonial geographies. New York: Guilford.

BRANDES, R. 1994. Drafting The price of stone: Richard Murphy's manuscripts for "Beehive cell". The Snow Path, 10:62-83.

CRANG, MIKE. 1998. Cultural geography. London: Routledge.

DEWSNAP, T. 1996. Richard Murphy's apologia: The price of stone. The Canadian Journal of Irish Studies, 22(1):71-86.

HEANEY, SEAMUS. 1977. The poetry of Richard Murphy. Irish University Review, 7(1):18-30.

MOYNAHAN, J. 1983. The battle of Aughrim: a commentary. Irish University Review, 7(1):103-113.

MURPHY, RICHARD. 1955. The archaeology of love. London: Dolmen.

MURPHY, RICHARD. 1963. Sailing to an island. London: Faber \& Faber.

MURPHY, RICHARD. 1964. The pleasure ground. (In Read, H., ed. Writers on themselves. London: British Broadcasting Corporation. p. 62-66.)

MURPHY, RICHARD. 1968. The battle of Aughrim. London: Faber \& Faber.

MURPHY, RICHARD. 1974. High Island. London: Faber \& Faber.

MURPHY, RICHARD. 1979. Selected poems. London: Faber \& Faber.

MURPHY, RICHARD. 1985. The price of stone and earlier poems. WinstonSalem: Wake Forrest University Press.

MURPHY, RICHARD. 1989a. New selected poems. London: Faber \& Faber.

MURPHY, RICHARD. 1989b. The mirror wall. Dublin: Wolfhound. 
MURPHY, RICHARD. 2001. Collected poems 1952-2000. Winston-Salem: Wake Forest University Press.

MURPHY, RICHARD. 2003. The kick: a life among writers. London: Granta Books.

SENDRY, J. 1985. The poet as builder: Richard Murphy's The price of stone. Irish University Review, 15(1):38-49.

SHEPPARD, Robert. 2000. The necessity of poetics. http://www. pores.bbk.ac.uk Date of access: 19 April 2000.

SIMMS, J.G. 1977. The battle of Aughrim: history and poetry. Irish University Review, 7(1):36-51.

WELCH, ROBERT. 1996. The Oxford companion to Irish literature. Oxford: Clarendon.

WENZEL, MARITA. 2003. Appropriating space and transcending boundaries in The Africa house by Christina Lamb and Ways of dying by Zakes Mda. Journal of Literary Studies, 19(3/4):316-330.

WILLIAMS, J. 1977. A glossary to The battle of Aughrim and The god who eats corn. Irish University Review, 7(1):73-103.

\section{Key concepts:}

autobiography

cultural geography

identity

poetics

space

\section{Kernbegrippe:}

identiteit

kultuurgeografie

outobiografie

poëtika

ruimte 